\title{
PSYCHOLOGICAL, NEUROPHYSIOLOGICAL AND THERAPEUTIC ASPECTS OF CHRONIC PAIN: PRELIMINARY RESULTS WITH TRANSCUTANEOUS ELECTRICAL STIMULATION
}

\author{
By H. J. HACHEN, M.D. \\ Spinal Injuries Centre, University Hospital, CH-I2II Geneva 4, Switzerland
}

\begin{abstract}
Psychological, neurophysiological and therapeutic aspects of chronic pain are reviewed in the light of recent progress achieved in the respective fields (alpha-feedback training; gate-control theory; transcutaneous electrostimulation; percutaneous stereoactic radio-frequency cordotomy). The efficacy of selective large fibre stimulation has been evaluated in 39 spinal cord injury patients suffering from chronic intractable pain of 6 to 35 months' duration. Stimulation was applied daily for 6 consecutive hours. Pain relief was assessed by verbal and visual analogue scales and McGill's pain questionaire. After I week, total or almost total relief of pain was reported by 49 per cent, moderate relief by 4I per cent and no improvement by Io per cent of the cases; at a 3-months followup the figures were 28 per cent, 49 per cent and 23 per cent respectively.
\end{abstract}

Key words: Chronic pain-diagnosis; assessment; treatment; pain inhibition by electrostimulation.

\section{Introduction}

PaIN is probably the single major complaint that causes a patient to seek a physician's help and advice. Through our daily practice we seem to have acquired much expertise in dealing with this topic, yet - upon closer analysis-we soon realise how ignorant we still are about most that relates to pain and suffering, particularly with regard to accurate definition, qualitative and quantitative assessment, understanding of the underlying mechanism of action and optimal therapy (Cherry, 1977). Pain should be viewed as a highly complex subjective mode of perception which is permanently modulated by an individual's emotional state and not as a primary sensory modality (Casey, I973; Zimmermann, 1976).

\section{Psychological Implications}

In patients with chronic pain one frequently encounters an apparent discrepancy between the degree of reported pain and objective clinical findings. Pain thresholds may vary considerably and within short time intervals depending on a large variety of psychological factors (Bonica, I973; Merskey, 1974). Thus, suffering involves considerably more than simple neuronal transmission of noxious peripheral input. The following bchavioural states have been shown to have major direct inplications in chronic pain:

Anxiety

Anxiety and anticipation considerably lower the threshold to noxious stimuli. Inversely, distraction often significantly increases tolerance for supraliminal noxious stimuli without inducing pain (Gerbershagen et al., 1975). This has been welldocumented by reports on severe trauma occuring during war or in sports (Wall \& Sweet, 1967). Several therapeutic measures such as suggestion, counter-irritation, acupuncture and more recently alpha-feedback training make direct use of this 
threshold-increasing property of distraction (Rabischong, 1975). Regular occupational therapy, social activities and active participation in sport similarly exert a beneficial effect.

\section{Depression}

Patients with chronic pain syndromes may gradually alter their behavioural attitude and develop signs of depression and frustration. On the contrary, some patients with primary endogenous depression tend to develop pain on purely perceptual, non-somatic grounds, as a sign of loneliness and despair. At a conscious or subconscious level they may overemphasize their suffering in order to receive more affection, sympathy and tender care.

\section{Resentment}

Resentment and irritability may gradually build up in a patient suffering from chronic unrelieved pain when he commences to doubt his physicians professional qualifications. Interpersonal conflicts, professional failure and unhappiness in married life all tend to lower tolerance for pain.

\section{Suggestion}

As documented by Melzack (1973) suggestion may be a valuable tool in making severe pain more tolerable. However, individual responses to placebo-effects vary considerably from person to person.

\section{Guilt}

Pilowsky (1976) has brought forward clear evidence that pain may serve to neutralise guilt. Intentional self-infliction of pain as a sign of repenting is already mentioned in the Old Testament. Pain was equated with punishment.

\section{Compensation}

Pain may be an outcry for help and constant attention from family and friends. Thus, a patient may attempt to use his pain in order to dominate his immediate surrounding. If he succeeds in achieving his goal, he most likely will respond negatively to all therapeutic efforts. Gratifying compensation may not only be obtained through closer interpersonal relationship, but also through direct financial reward. As long as a legal case is pending pain abides.

\section{Neurophysiological Aspects}

Conduction of pain is presently thought to occur along two different pathways:

The oligosynaptic system of the spinothalamic tract that terminates in the ventral postero-lateral nucleus of the thalamus and secondly the multisynaptic afferent system (MAS) that allows peripheral sensory input to enter at various levels of the spinal cord and extends to the reticular formation of the brain stem.

In recent years two major contributions have been made towards better understanding of pain mechanisms: One is Melzack and Wall's gate-control theory established in I965, the other known as 'pattern theory' tends to replace the previously adopted 'specificity theory' (Casey, I973).

\section{Gate-control Theory}

It is now assumed that noxious stimuli produce primary afferent (presynaptic) hyperpolarisation $(\mathrm{PAH})$, with a strong excitatory input, whereas non-noxious 
stimuli cause primary afferent depolarisation (PAD) (Collins et al., I960; Hodge, 1968). According to the original gate-control theory, stimulation of large myelinated fibres induces presynaptic inhibition (Perl, 1969) and subsequently prevents transmission of nociceptive impulses passing through A-gamma and delta and Cfibres which belong respectively to group III of the small myelinated and group IV of the non-myelinated fibres (Wall, I964). These latter structures have been shown to exert a facilitatory effect on ongoing activity in the dorso-lateral T-cells (transmission cells): they are primarily involved in pain transmission. The intensity of noxious sensory input may be attentuated by the substantia gelatinosa (SG) which exerts a presynaptic inhibitory function. Evidence has accumulated that the gatecontrol is continuously modulated by postsynaptic mechanisms (Mayer \& Price, 1976). The antidromic activity arising in the central nervous system is of major physiological importance. Postsynaptic mechanisms also account for certain states of hyperalgesia or persistent pain after withdrawal of a noxious stimulus. Intense peripheral input may trigger the $\mathrm{T}$-cell in the dorsal horn which is capable of maintaining repetitive neurone activity (post-tetanic potentiation, PTP) of its own. This clearly shows that the spinal cord is not just a conduction system, receiving environmental impulses through the dorsal roots and passing them on to the brain. In fact both efferent reflex activity and modulation of afferent input occur in the spinal cord itself. It has, furthermore, been possible to demonstrate that dorsal root activity may temporarily block orthodromic afferent inputs.

\section{Central Inhibitory Mechanisms}

In a recently published study Kerr (1975) provides clear evidence for the existence of complex central inhibitory factors. Mayer and Liebeskind (1974) have been successful in reducing pain by elective stimulation of the brain. Melzack and Melinkoff (1974) have shown that the analgesic effect frequently outlasts the period of central stimulation, a finding that also applies to peripheral transcutaneous stimulation. Oliveras et al. (1974) have identified the structures of the mid-brain that initiate particularly potent analgesic activity upon electrostimulation. In man, Richardson (1976) has recorded remarkable analgesic effects during stimulation of the periaqueductal grey matter (PAG). This structure probably contains a morphine-like endogenous neurotransmitter agent which initiates central inhibition of peripheral nociceptive input. Stimulation produced analgesia (SPA) and morphine analgesia have several points in common. Both are brought about by inhibition of transmission at the level of the spinal cord and both are abolished by selective destruction of the dorsolateral column. From the neurophysiologist's point of view it is interesting to note that SPA may engender selective inhibition of pain in a well-defined peripheral territory. With regard to neurohumoral factors involved in SPA there still persists much controversy. Serotonin, norepinephrine, dopamine and enkephalin all seem to be involved to some extent. Serotonin is likely to be of primary importance, since its depletion with chlorophenylalanine significantly decreases or even abolishes SPA.

\section{Classification of Pain}

Pain may be classified according to its frequency, intensity duration, aetiology, amenability to treatment and interference with normal daily activity. In patients with spinal cord injury (Burke, I973: Davis, 1975) pain is likely to arise from one of the following three sites:

Location of spinal injury, particularly in patients showing severe deformity of the 
spine. Painful stimuli may be initiated by chronic irritation to the distal end of the proximal intact segment of the cord. Neurosurgical procedures such as decompression laminectomies with or without concomitant fusion are well-known contributing factors. Rarely pain may be related to a delay in consolidation.

Radicular origin, predominantly after severe fracture-dislocations involving traction and tearing of the roots and in patients showing evidence of post-traumatic adhesive arachnoiditis.

Phantom pain with referral to zones below the level of injury. This may be further subdivided into two categories: early disagreeable phantom sensations that regress within a few weeks or months and intractable chronic phantom pain that occurs mostly in patients with cauda equina lesions.

In tetraplegics, neglect of early physiotherapy may induce severe pain in the shoulders and elbow joints. This can still be observed in patients receiving initial treatment outside of a paraplegic centre.

Finally, certain types of pain such as 'tension headache' may be caused by enhanced interoceptive noxious input originating in the autonomous system, for instance during distension of the bladder and bowel.

\section{Assessment of Pain}

Pain, as outlined above, is essentially a subjective phenomenon, and we all know how difficult it is to transcribe subjective responses into meaningful quantitative data (Merskey, I973; Merskey, I974). In neurophysiological animal experiments it is relatively easy to determine pain thresholds for well-defined electrical, mechanical, thermal and chemical stimuli. However, experimentally induced pain and clinically observed pain syndromes only have very few characteristics in common, and the results of the former are not necessarily relevant with regard to the latter.

Since in daily practice we necessarily rely on verbal information obtained from our patients, 'descriptive words' probably are the most practical aid in measuring pain. When analysing a patient's description of his suffering we must clearly distinguish between the report of pain and actual sensation of pain. These terms are often misinterpreted as being identical. In fact, 'sensation of pain' measures discriminability and remains unaltered when attitudinal factors are involved. The report of pain, on the contrary, is strongly influenced by an individual's momentary psychological state. Thus many pain threshold changes reported in the literature may have been largely due to variations in the criteria for reporting pain and not to actual modifications in pain sensivity. The sensory decision theory (SDT) emphasises the distinction between pain experience in itself and a person's criteria for reporting pain. This theory accounts for the common observation that low intensity non-noxious stimuli may occasionally be painful, while noxious stimuli, applied shortly thereafter may be non-painful. Merksey (1974) proposes the following parameters for measuring pain:

Pain threshold. This should be evaluated by gradually increasing and subsequently decreasing the stimulus, since ascending and descending limits may show considerable variations. Threshold measurements obtained by the descending method are significantly higher than the ones found with the ascending method. It should also be remembered that continuous pain confined to one part of the body may significantly increase pain thresholds in other areas. Thus, relief of severe segmental pain by dorsal rhizotomy has occasionally been followed by new and previously unrecognised pain in other territories. 
Point of Maximum Tolerance

Pain sensitivity range (difference between ascending threshold and maximum tolerance).

\section{Response to Noxious Stimuli of Fixed Parameters}

Rating scales:

(a) Verbal. The following simple score may be used: absent, slight, moderate, severe.

(b) Visual. Pain intesity is expressed in $\mathrm{mm}$ on a $10 \mathrm{~cm}$ horizontal measuring scale carrying on the left the mention 'no pain' and on the right the indication 'the pain is as much as I can bear'. Both methods have the advantage that they may be applied repeatedly without inconvenience to the patient. Merskey (1974) has shown that there is a good correlation between both rating scales $(r>0.8$; $\mathrm{P}<0.01$ ).

(c) Auditory. The degree of pain is compared to intensity of sound.

The pain modulating action of psycho-emotional factors such as anxiety and depression may be assessed with the aid of various personality questionnaires such as the Minnesota Multiphasic Personality Inventory (MMPI).

\section{Relief of Pain}

Before attempting any therapeutic action, it is essential to obtain precise information regarding the patient's past history, his age, general health condition, psychological state, social and family background and professional activity and to carefully analyse the characteristics of his particular pain syndrome with regard to location, intensity, frequency and duration.

Relatively mild pain caused by peripheral injury responds positively to a variety of therapeutic means. The so-called problem case is the young, professionally active patient with chronic, intractable pain of non-malignant aetiology. Total and permanent relief of chronic pain is seldom achieved. Our therapeutic efforts should therefore be aimed at reducing unbearable and truly disabling pain to a more tolerable level. Prognosis and efficacy of treatment should be considered not only in terms of immediate relief of pain but also with regard to long-term functional improvement. Although neurosurgical pain-relieving techniques have been considerably improved in recent years, proper management of pain still remains largely conservative. The scalpel and stereotactic probe should be strictly limited for those cases that remain unchanged after conservative measures have been applied correctly and for a sufficiently long time.

\section{Conservative Therapy}

Analgesic medication: mild analgesics, narcotic drugs, tranquilisers and antidepressants (Parkhouse, 1975).

Modulation of behavioural state: suggestion, psychotherapy, hypnosis and alpha-feedback training. This latter technique does not change the threshold for pain sensation, but modifies the patient's interpretation of and reaction to pain.

Non-noxious peripheral counter-irritation: this therapeutic approach is based on the observation that non-noxious large-fibre input competes with noxious smallfibre input and thus lowers or abates pain. The following techniques have been proposed: 
Acupuncture (Diamond, 197I; Mann et al., 1973; Anderson et al., 1974; Melzack, I976).

Cryoanalgesia (Lloyd et al., 1976). This method produces a reversible peripheral nerve block and is therefore particularly indicated in patients with incomplete lesions and when motor function has to be preserved. Best results are obtained in pain due to peripheral nerve injury.

Transcutaneous electrical stimulation. The potent analgesic effect of direct peripheral nerve stimulation has already been described a decade ago by Wall and Sweet (1967). Presently two different methods are available: low-intensity stimulation, applied for several hours at a time, selectively activates large fibre input and closes the gate in the dorsal horn of the spinal cord. High-intensity stimulation, usually applied for short periods only, increases predominantly small fibre input. Though this procedure may be slightly painful in itself, it triggers antidromic inhibitory activity in the brain stem and thus blocks transmission of more powerful pain stimuli arising from other areas. Over the past 3 years a large series of well-controlled clinical trials has added further evidence indicating that both types of stimulation may provide significant, lasting relief of pain (Campbell, I973; Hymes et al., 1974; Shealy, 1974; Cauthen, 1975; Ebersold et al., I975; Loeser et al., 1975; Picaza et al., I975; Rutkowski et al., I975; Fux, 1976; Linzer, 1976; Sternbach et al., 1976). In patients with peripheral nerve injury positive results may be expected in approximately 75 per cent of the cases. In phantom pain beneficial effects are reported in the range of 45-60 per cent.

Dorsal column stimulation (Shealy et al., I970; Hosobuchi et al., I972; Nashold, I972; Miles et al., I974; Nielson et al., 1975). This technique is now routinely used prior to permanent implantation of a stimulating device.

Nerve blocks. Peripheral and subarachnoid phenol blocks (Evans, I972).

\section{Surgical Procedures}

In permanently interrupting sensory pathways, all proposed techniques are essentially destructive procedures.

Peripheral neurectomy is rarely indicated since pathology is usually not confined to a single innervation territory.

Dorsal rhizotomy (Echols, 1970; Loeser, 1972; White, 1973) is mainly indicated in relieving pain arising from isolated severely injured roots. The long-term success rate does not exceed 30 per cent, though early relief of pain has been achieved in as much as 65 per cent. Due to overlapping segmental innervation, at least three adjacent roots must be sectioned. Therefore the technique usually requires a laminectomy at four or more levels.

Commisursal myelotomy (Papo, I976) likewise has only limited applicability. The method consists in sectioning the spinothalamic fibres as they cross from the dorsal horn to the spinothalamic tract. It requires a midline, sagittal incision of the spinal cord. In patients with incomplete lesions this technique carries a major risk of neurological aggravation.

Antero-lateral cordotomy (White, I969; Loeser, I973; Mayer et al., 1975) abolishes both temperature and pain sensation. It should preferably be carried out at the cervical level where there seem to be less complications. The pain-relieving effect of cordotomy is explained by the fact that the dorsal horn $\mathrm{T}$-cells project into the spinothalamic tract. Onofrio (I97I) has developed a new and less traumatic technique of percutaneous radiofrequency cordotomy. In well-selected cases immediate relief of pain can be obtained in about 85 per cent of the cases; however, 
there is a $35-40$ per cent recurrency rate within 6 months. Bilateral upper cervical cordotomy should be avoided since it may cause severe respiratory failure.

Psychosurgery. Leucotomy, stereotactic cingulotomy (Pool, I954; Richardson, I967) and various other techniques of psychosurgery have been proposed to relieve chronic intractable pain in patients with severe psychoaffective disorders. Postoperatively pain is still perceived, but no longer interpreted as suffering. None of our patients has ever required such a procedure, and we find it difficult to assess the true benefit derived from these techniques when analysing the isolated case reports published in the recent literature.

\section{Transcutaneous Electrical Stimulation; Personal Investigation}

Subjects. Thirty-nine spinal cord injury patients with intractable pain of 6 to 35 months' duration were enrolled in this stuay. 'The age, sex, level and type of lesion are indicated in Table I.

\section{Description and Location of Pain}

Group I. Twenty-two cases (all paraplegics with lower dorsal or lumbar lesions) described their pain as being located at the site of spinal injury.

Group II. Eleven cases (Five para- and six tetraplegics) showed radicular distribution of pain.

Group III. Six cases (five cauda equina lesions and one tetraplegia) were suffering from phantom pain.

In group I, six patients had initially been treated by decompression laminectomy without fusion, three had a laminectomy with subsequent posterolateral fusion and two anterior decompression followed by anterior fusion. Thus, half of the patients in this series had initially been submitted to surgery.

\section{Previous Therapy}

Prior to this investigation all patients required relatively large daily doses of pentazocine (100-200 mg), paracetamol (600-900 mg), amitriptyline (75-150 mg) and carbamazepin (600-800 $\mathrm{mg}$ ), either alone or in various combinations.

One patient in group III previously had unsuccessful dorsal column stimulation, followed by unsuccessful antero-lateral quadrant cordotomy.

Out of I 6 patients who had initially returned to work, I 2 gradually abandoned all professional activity because of pain.

\section{TABLE I}

Age, sex, level and type of spinal cord injury of 39 patients with chronic pain syndromes (mean age: 3 I years)

\begin{tabular}{|c|c|c|c|c|c|c|c|}
\hline \multicolumn{4}{|c|}{$\begin{array}{c}25 \text { Men } \\
\text { (Mean age : } 28 \text { years) }\end{array}$} & \multicolumn{4}{|c|}{$\begin{array}{c}\text { I4 Women } \\
\text { (Mean age : } 36 \text { years) }\end{array}$} \\
\hline \multicolumn{2}{|c|}{ 2I Paraplegics } & \multicolumn{2}{|c|}{4 Tetraplegics } & \multicolumn{2}{|c|}{ I I Paraplegics } & \multicolumn{2}{|c|}{3 Tetraplegics } \\
\hline $\begin{array}{c}\text { Io } \\
\text { Complete }\end{array}$ & $\begin{array}{c}\text { I I } \\
\text { Incomplete }\end{array}$ & $\stackrel{\text { I }}{\text { Complete }}$ & $\stackrel{3}{\text { Incomplete }}$ & $\begin{array}{c}6 \\
\text { Complete }\end{array}$ & $\stackrel{5}{\text { Incomplete }}$ & $\stackrel{\text { I }}{\text { Complete }}$ & $\stackrel{2}{\text { Incomplete }}$ \\
\hline
\end{tabular}




\section{Characteristics of Transcutaneous Stimulation}

Low-intensity electrostimulation was administered with a portable 'Staodyn 4000' stimulator. ${ }^{1}$ The stimulation parameters are indicated in Table III. During the first week, treatment was applied daily for 6 consecutive hours; thereafter the frequency, duration and intensity were gradually adapted to individual patient requirements. Correct electrode location is of paramount importance. It may take several days before optimal stimulation sites can be determined.

\section{Results}

The criteria used for evaluation of the method are provided in Table II.

The pain rating index (PRI) (Fig. I), present pain intensity (PPI) (Table IV) and visual analogue number (Fig. 2) have been evaluated daily before and after stimulation. Thereafter these measurements were obtained at weekly intervals. The duration of pain relief is indicated in Figure 3.

Initial PRI- and PPI-values were highest for phantom pain, to be followed by pain of radicular origin and pain at the site of vertebral injury.

Positive response to stimulation could rarely be elicited before 4 to 5 days (this may be due to initial difficulties in defining optimal trigger-zones). Placebo stimulation caused a slight, though non-significant improvement of the PRI index in a small group of patients with radicular pain (Fig. I). As treatment progressed, pain relief frequently outlasted the time of stimulation by several hours (Fig. 3). Considering the total group of 39 patients, early (I week) results are significantly better than late (3 months) results.

After the first 7 days of treatment 49 per cent of the cases reported complete or almost complete and $4 \mathrm{I}$ per cent slight relief of pain. Upon re-evaluation at the end of the third month the figures were 28 per cent and 49 per cent respectively.

\section{Contra-indications}

In patients carrying a cardiac pacemaker, bladder stimulator or other electronic device, transcutaneous electrical stimulation is contra-indicated. Otherwise there are no particular restrictions or precautions. Local skin tolerance to long-term stimulation has been excellent.

\section{TABLE II}

Criteria used for assessment of analgesic effect of transcutaneous stimulation
(A) Subjective pain relief
(Visual analogue scale; PRI: Pain rating index
(B) Request for analgesic drugs
(C) Pattern of sleep
PPI: Present pain intensity)
(Type of Drug and dosage)
(Mode of induction; number of hours; subjective feeling upon waking up)
(D) Psychological state
(E) Level of daily activities
(Depression, Hostility, etc.)
(Professional, social and recreational)

1 J. A. Preston Corporation, 7I Fifth Avenue, New York, N.Y. I0003. 

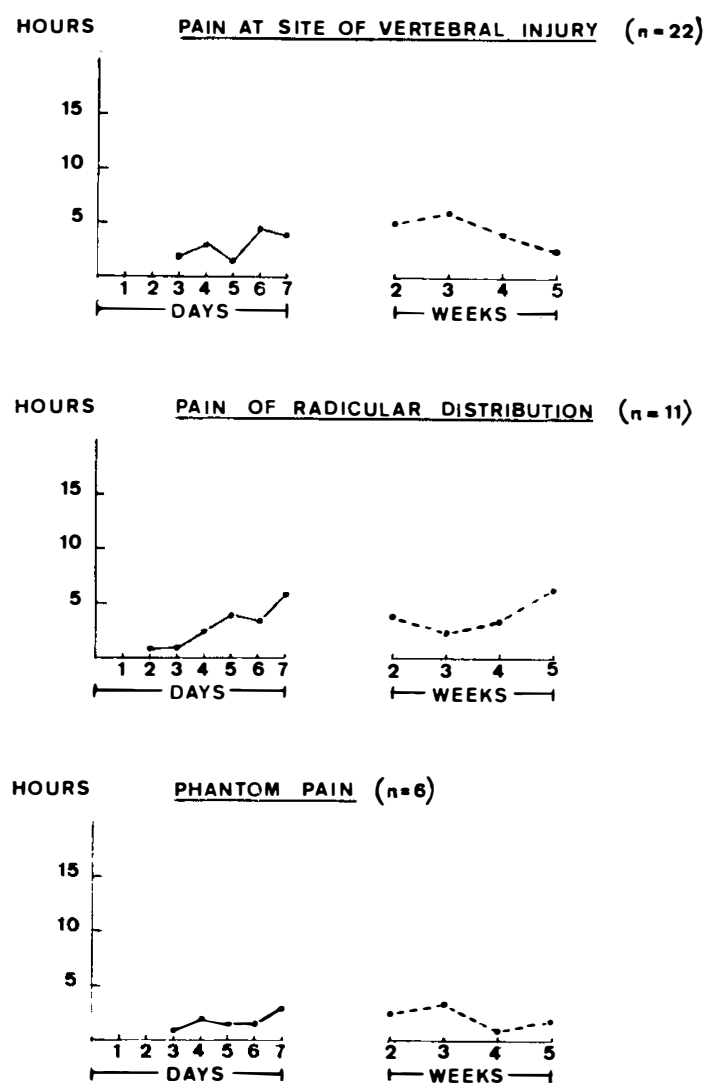

- $\longrightarrow$ fixed stimulation parameters (first week)

-..... Variable stimulation parameters

FIG. I

Pre- and poststimulation assessment of pain rating index (PRI). (Mean values and standard deviations.)

\section{TABLE III}

Stimulus parameters (Staodyn 4000)

Pulse shape

Pulse duration

Pulse frequency

Current density

Power density

Power source
Rectangular with zero net d.c. component I-IO microseconds $40-180 / s e c$. $0 \cdot 2-0 \cdot 8 \mu \mathrm{A} / \mathrm{mm}^{2}$ 8-64 $\mu$ watt $/ \mathrm{mm}^{2}$ 2 'AA' NiCd rechargeable cells 

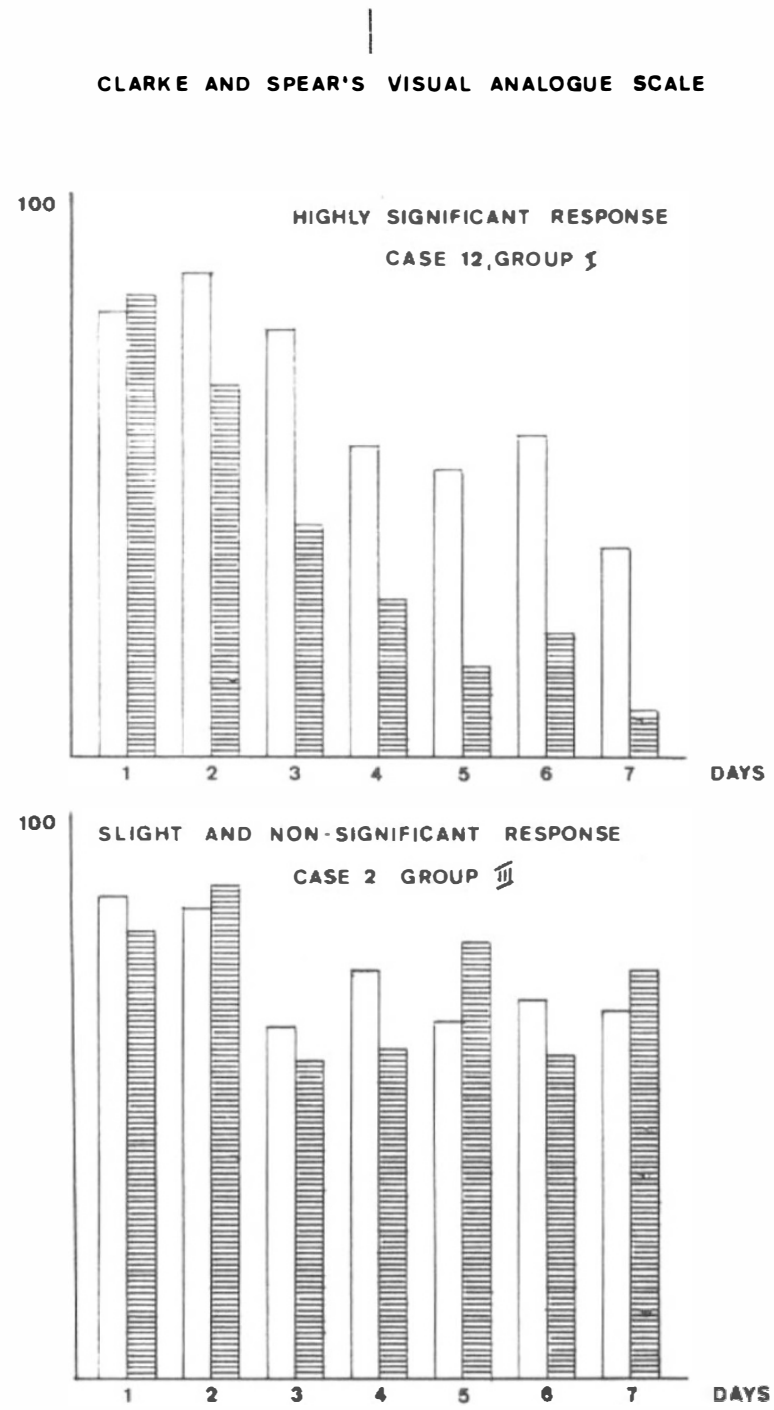

FIG. 2

Pre- and poststimulation assessment of pain intensity.

\section{SUMMARY}

Our preliminary results with transcutaneous, low-intensity electro-stimulation in a group of 39 spinal cord injury patients suffering from chronic intractable pain of 6 to 35 months' duration seem to show that this relatively new, non-invasive technique may cause significant pain relief in approximately one-third of the cases. However, longer follow-up evaluation must be awaited before drawing any definite conclusions. 

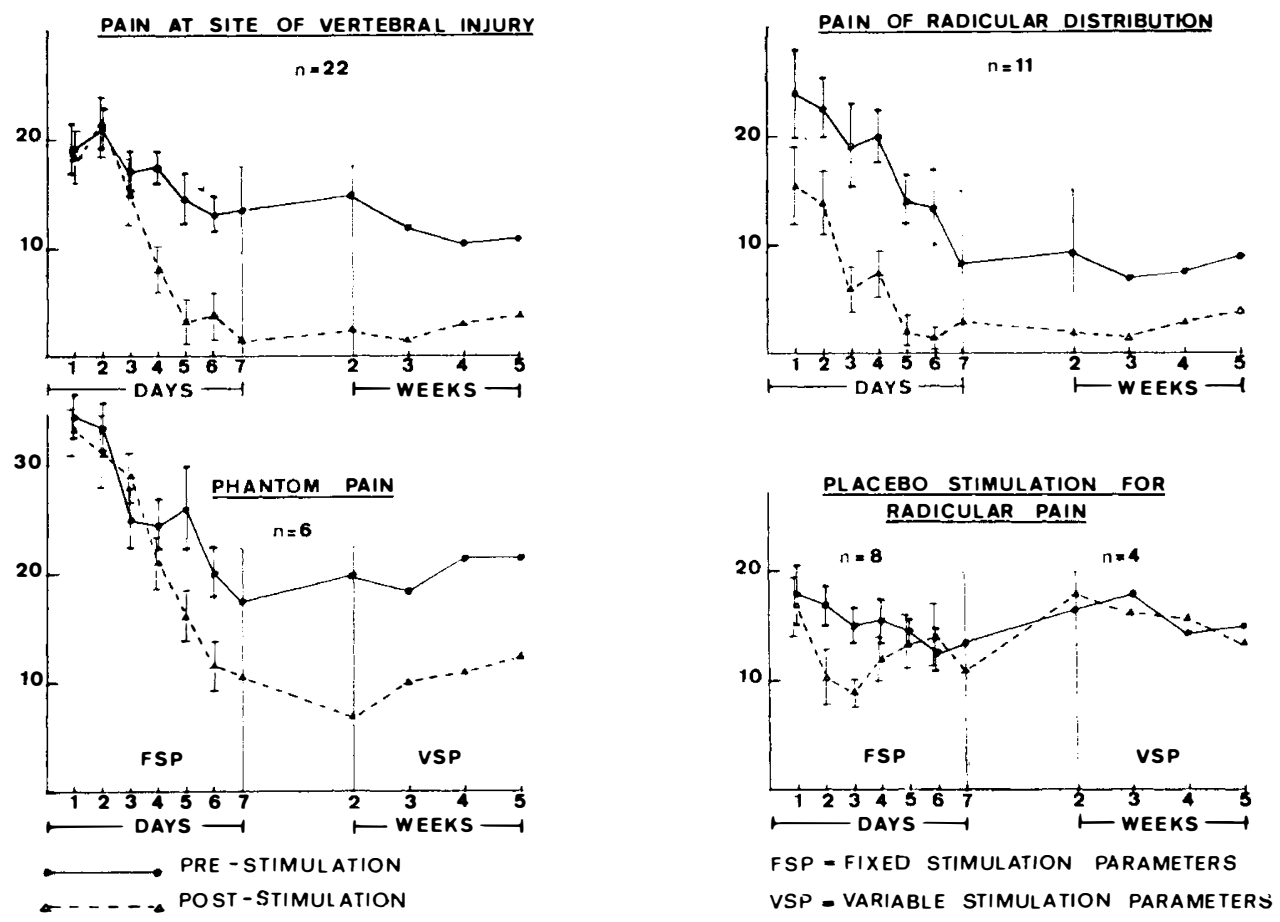

FIG. 3

Duration of pain relief following low-intensity transcutaneous electrostimulation.

\section{TABLE IV}

Mean present pain intensity (PPI) and the pain rating index (PRI) before and after one week of TC-electrostimulation measured by four daily recordings

\begin{tabular}{|c|c|c|c|c|c|}
\hline \multirow[t]{2}{*}{ Type of pain } & \multirow[t]{2}{*}{$N$} & \multicolumn{2}{|c|}{ Before stimulation } & \multicolumn{2}{|c|}{ After stimulation } \\
\hline & & $\overline{\mathrm{PPI}}$ & $\overline{\mathrm{PRI}}$ & $\overline{\mathrm{PPI}}$ & PRI \\
\hline \multicolumn{6}{|l|}{ Pain at site of } \\
\hline Pain of radicular & & & & & \\
\hline origin & I I & 2.6 & 24.0 & I. 5 & 8.5 \\
\hline Phantom pain & 6 & 3.1 & $34 \cdot 5$ & I.9 & I 7.5 \\
\hline
\end{tabular}

PPI scale: I, mild; 2, discomforting; 3, distressing; 4, horrible; 5, excruciating. $15 / 4-F$ 
TABLE V

Early and late results of electrical transcutaneous stimulation

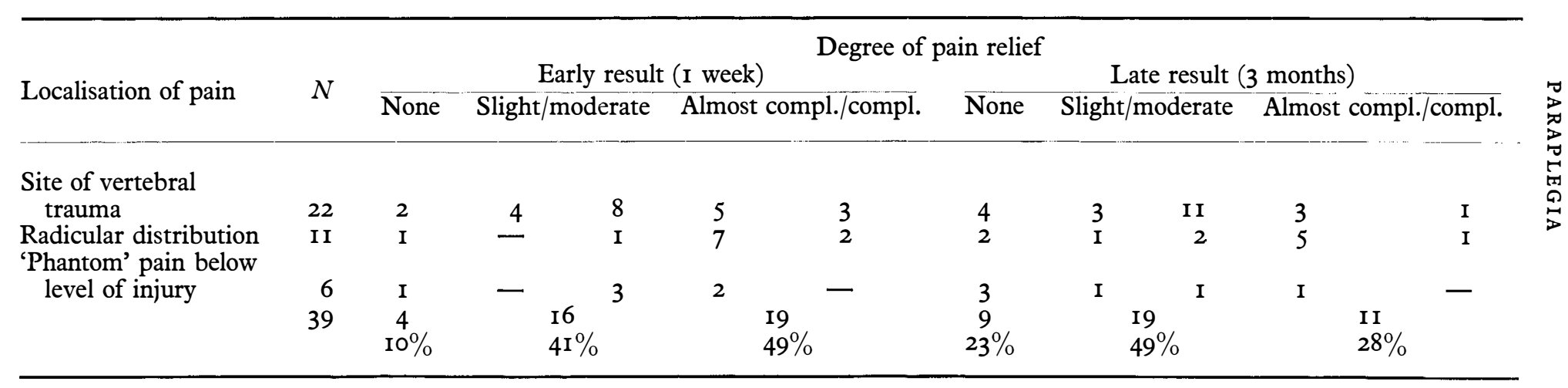




\section{RÉSUMÉ}

Nos résultats préliminaires, obtenus avec l'électrostimulation transcutanée de faible intensité chez 39 traumatisés médullaires attéints de divers syndromes douloureux de 6 à 35 mois d'évolution, semblent indiquer que cette méthode relativement nouvelle, facilement applicable et bien tolérée, exerce une action antalgique significative dans environ un tiers des cas traités. Toutefois, le temps de recul nous parait encore trop court pour pouvoir porter un jugement définitif sur l'efficacité à long terme de cette méthode.

\section{ZUSAMMENFASSUNG}

Unsere erste Erfahrung mit der Methode der perkutanen Elektrostimulation bei 39 Querschnittgelähmten mit schweren, seit 6 bis 35 Monaten andauernden Schmerzsyndromen, weisen darauf hin, dass dieses neue und gut verträgliche Verfahren bei etwa einem Drittel der Patienten zu signifikanter Schmerzbefreiung führt. Zu einer endgültigen Beurteilung fehlt uns jedoch noch der notwendige Rückblick.

\section{REFERENCES}

Anderson, D. G., JAmieson, J. L. \& MAN, S. C. (I974). Analgesic effects of acupuncture on the pain of ice-water. Canad. F. Psychol., 28, 239-244.

Atrinson, L. (1976). The management of the intractable pain. Med. F. Aust., I, 786-788.

Bailey, A. A. \& Moersch, F. P. (I94I). Phantom limb. Canad. Med. Assoc. F., 45, 37-42.

BonICA, J. J. (1973). Fundamental considerations of chronic pain therapy. Postgrad. Med., 53, 8I-85

Bourke, R. S. (1976). Pain and its relief. Int. F. Radiation Oncology Biol. Phys. I, 5I I-5I4.

BuRKe, D. C. (1973). Pain in paraplegic. Paraplegia, 10, 297-313.

Campbell, J. B. (I966). Painful phantom limb: relief through peripheral nerve surgery, in Knighton, R. S., Dumke, P. R. (eds): Pain: Henry Ford Hospital International Symposium, 225-27I.

CAMPBELL, J. B. \& TAUB, A. (1973). Local analgesia from percutaneous electrical stimulation Arch. Neurol., 28, 347-350

Casey, K. L. (1973). The neurophysiological basis of pain. Postgrad. Med., 53, 58-63.

CAUTHEN, J. C. \& RENNER, E. J. (1975). Transcutaneous and peripheral nerve stimulations for chronic pain states. Surg. Neurol., 4, I02-104.

Cherry, L. (1977). Solving the mysteries of pain. N.Y. Times Magazine, 50, I2-I3.

Collins, W. F., Nulsen, F. E. \& RANDT, C. T. (1960). Relation of peripheral nerve fibre size and sensation in man. Archs. Neurol. Chicago, 3, 38I-385.

Davis, R. (1975). Pain and suffering following spinal cord injury. Clin. Orthop., 11 2, 76-80.

Diamond, E. G. (I97I). Acupuncture anesthesia. F. Am. Med. Ass., 218, I 558.

DRAKE, C. G. \& MCKenZIE, K. G. (I953). Mesencephalic tractomy for pain. F. Neurosurg., I0, 457-462.

Ebersold, M. J., Laws, E. R., Stornington, H. H. \& Stillwell, G. K. (I975). Transcutaneous electrical stimulation for treatment of chronic pain. Surg. Neurol., 4, 96-99.

Echols, D. H. (1970). The effectiveness of thoracic rhizotomy for chronic pain. Neurochirurgia, 13, 69-74.

Evans, R. J. \& MACKAY, I. M. (1972). Subarachnoid phenol nerve blocks for relief of pain in advanced malignancy. Canad. F. Surg., 15, 50-53.

FALCONER, M. A. (1953). Surgical treatment of intractable phantom-limb pain. Br. Med. 7., 1, 299-304.

Fux, E. J. \& MELZACK, R. (1976). Transcutaneous electrical stimulation and acupuncture. Pain, 2, I4I-I48.

Gerbershagen, H. U., Frey, R., Magnin, F., Scholl, W. \& Mueller-SuUR, N. (I975). The pain clinic. Br. F. Anaesth., 47, 526-529.

HodGE, C. J. (1972). Potential changes inside central efferent terminals secondary to stimulation of large and small diameter peripheral nerve fibers. F. Neurophysiol., 35, 30-43.

Hosobuchi, Y., Adams, J. E. \& Weinstein, P. R. (1972). Preliminary percutaneous dorsal column stimulation prior to permanent implantation. F. Neurosurg., 37, 242-245.

Hymes, A. C., RaAb, D. E., Yonehiro, E. G., Nelson, G. D. \& Printy, A. L. (1974). Acute pain control by electrostimulation. Adv. in Neurol., 4, 76I-767.

KerR, F. W. L. (1975). Pain, a central inhibitory balance theory. Mayo Clin. Proc., 50, 685-690. 
Lazorthes, Y., Verdie, J. D. \& LAgarrigue, J. (I976). Thermocoagulation percutanée des nerfs rachidiens à visée analgésique. Neuro-Chirurgie, 22, 445-453.

LINZER, M. \& LONG, D. M. (I976). Transcutaneous neural stimulation for relief of pain. IEEE Transactions Biomed. Eng. B.M.E., 23, 34I-345.

Lipton, S. (1975). The treatment of intractable pain. Practioner, 215, 46I-467.

Lloyd, J. W., BARNARD, J. D. W. \& GlynN, C. J. (1976). Cryoanalgesia, a new approach to pain relief. Lancet, Oct., 30, 932-934.

LoESER, J. D. (1972). Dorsal rhizotomy for the relief of chronic pain. F. Neurosurg., 36, 745-750.

Loeser, J. D. (I973). Neurosurgical relief of chronic pain. Postgrad. Med., 53, I I5-I I9.

LOESER, J. D., BLACK, R. \& Christman, A. (I975). Relief of pain by transcutaneous stimulation. F. Neurosurg., 42, 308-3I4.

ManN, F., Bowsher, D., Mumford, J., Lipton, S. \& Miles, J. (1973). Treatment of intractable pain by acupuncture. Lancet, $\mathbf{I}, 57-60$.

Mayer, D. J. \& Liebeskind, J. C. (I974). Pain reduction by focal electrical stimulation of the brain; an anatomical and behavioral analysis. Brain Res., 68, 73-93.

MaYer, D. J., Price, D. D., BECKER, D. F. \& YounG, H. F. (I975). Threshold for pain from anterolateral quadrant stimulation as a predictor of success of percutaneous cordotomy for relief of pain. F. Neurosurg., 43, 445-447.

MaYer, D. J. \& Price, D. D. (1976). Central nervous system mechanism of analgesia. Pain, 2, 379-404.

MelzaCK, R. (I97I). Phantom limb pain: implication for treatment of pathologic pain. Anesthesiology, 36, 409-419.

Melzack, R. (I975). The McGill pain questionnaire: major properties and scoring methods. Pain, I, 277-299.

MelzaCK, R. (I975). Prolonged relief of pain by brief, intense transcutaneous somatic stimulation. Pain, I, 357-373.

MelzACK, R. (1976). Akupunktur und Schmerzbeeinflussung. Anaesthesist, 25, 204-207.

Melzack, R. \& MelinkofF, D. F. (1974). Analgesia produced by brain stimulation: evidence of a prolonged onset period. Exp. Neurol., 43, 369-374.

Melzack, R. \& Wall, P. D. (1965). Pain mechanism: a new theory. Science, 150, 971978.

Merskey, H. (1973). The perception and measurement of pain. F. Psychosomatic Res., I 7, $25 \mathrm{I}-255$.

MerSKEY, H. (1974). Assessment of pain. Physiotherapy, 60, 96-98.

Merskey, H. (1974). Psychological aspects of pain. Current Med. Res. and Opinion, 2, 515-520.

MEYER, G. \& FIELDS, H. (I972). Causalgia treated by selected large fiber stimulation of peripheral nerve. Brain, 95, I63-168.

Miles, J., Lipton, S., Hayward, M., Bowsher, D., Mumford, J. \& Molony, V. (1974). Pain relief by implanted electrical stimulation. Lancet, I, 777.

Nashold, B. S. \& FRIEDMAN, H. (I972). Dorsal column stimulation for control of pain. F. Neurosurg., 36, 590-597.

Neilson, K. D., Adams, J. E. \& Hosobuchi, Y. H. (1975). Phantom limb pain; treatment with dorsal column stimulation. F. Neurosurg., 42, 30I-307.

Oliveras, J. L., Besson, J. M., Guillaud, G. \& LiebeSkind, J. C. (I974). Behavioral and electrophysiological evidence of pain inhibition from midbrain stimulation. Exp. Brain Res., 20, 32-44.

ONOFRIO, B. M. (I97I). Cervical spinal cord and dentate delineation in percutaneous radiofrequency cordotomy at the level of the first to second cervical vertebrae. Surg. Gynec. \& Obst., 133, 30-34.

Papo, I. \& LuONGO, A. (I976). High cervical commissural myelotomy in the treatment of pain. F. Neurol. Neurosurg. Psychiat., 39, 705-710.

Parkhouse, J. (1975). Drug treatment of pain. Anaesthesia, 30, 338-345.

PAwL, R. P. (I975). Percutaneous radiofrequency electrocoagulation in the control of chronic pain. Surg. Clin. N. Amer., 55, 167-1 79.

Perl, E. R. (I968). Myelinated afferent fibers innervating the primate skin and their response to noxious stimuli. F. Physiol., 197, 593-615.

Picaza, J., Cannon, B., Hunter, S., Boyd, A., Guma, J. \& Maurer, D. (1975). Pain suppression by peripheral nerve stimulation. Surg. Neurol., 4, I05-I24.

PILowsky. I. (1976). The psychiatrist and the pain clinic. Am. F. Psychiatry, 133, 75I756. 
Pool, J. L. \& BRIDGes, T. J. (I954). Subcortical parietal lobotomy for relief of phantom limb syndrome in upper extremity. Bull. N.Y. Acad. Med., 30, 302-309.

Rabischong, P. (1975). Les problèmes-clés de la douleur. Nouvelle Presse Médicale, 4, 2013-2015.

RichaRDSON, D. E. (1967). Thalamotomy for intractable pain. Confin. Neurol., 20, I39-I 45.

RICHARDSON, D. E. (I976). Brain stimulation for pain control. IEEE Transection. B.M.E., 23, 304-307.

RutKowski, B., Niedzialkowska, T. \& Otтo. J. Electrostimulation in the management of chronic pain. Anaesthesist, 24, 457-460.

ShEALY, C. N. (I974). Six year's experience with electrical stimulation for control of pain. Adv. in Neurol., 4, 775-782.

SheAly, C. N. (I975). Percutaneous radiofrequency denervation of spinal facets. $\mathcal{F}$. Neurosurg., 43, 448-45I.

SheAly, C. N. \& MAURER, D. (1974). Transcutaneous nerve stimulation for control of pain. Surg. Neurol., 2, 45-47.

Shealy, C. N., Mortimer, J. T. \& Hagfors, N. R. (1970). Dorsal colum electroanalgesia. f. Neurosurg., 32, 560-564.

SPILLER, W. G. \& MARTIN, E. (I9I4). The treatment of persistent pain of organic origin in the lower part of the body by division of the anterolateral colum of the spinal cord. F.A.M.A., 58, I489-1 490 .

Sternbach, R. A., Ignelzi, R. J., Deems, L. M. \& Timmermans, G. (I976). Transcutaneous electrical analgesia; a follow-up analysis. Pain, 2, 35-4I

Sternschein, M. J., Myers, S. J., Freum, D. B. \& Downey, J. A. (1975). Causalgia. Arch. Phys. Med. Rehab., 56, 58-63.

StONE, T. T. (I950). Phantom limb pain and central pain. Relief by ablation of a portion of posterior central cerebral convolution. Arch. Neurol. Psychiat., 63, 739-749.

SwEET, W. H. (1975). Phantom sensations following intraspinal injury. Neurochirurgia, 18, I39-I 54.

WALl, P. D. (1964). Presynaptic control of impulses at the first central synapse in the cutaneous pathway. Prog. Brain Res., 12, 92-II 5.

Wall, P. D. \& GutTNICK, M. (1974). Properties of afferent nerve impulses originating from a neuroma. Nature (Lond.), 248, 740-743.

Wall, P. D. \& SWEET, W. H. (I967). Temporary abolition of pain. Science, 155, I08-Io9.

White, J. C. \& KJellberg, R. N. (I973). Posterior spinal rhizotomy: a substitute for cordotomy in the relief of localised pain in patients with normal life expectancy. Neurochirurgia, 16, I4I-I70.

White, J. C. \& SWEet, W. H. (1969). Pain and the Neurosurgeon. A Forty Year Experience. Springfield, Ill. Charles C. Thomas.

ZimmermanN, M. (1976). Neurophysiologische Grundlagen von Schmerz und Schmerztherapie. Langenbecks Arch. Chir., 242, 63-74. 